\title{
Retraction: The stem cell factor antibody enhances the chemotherapeutic effect of adriamycin on chemoresistant breast cancer cells
}

Neil D Jelly ${ }^{1 *}$, Issam I Hussain ${ }^{1}$, Jennifer Eremin ${ }^{2}$, Oleg Eremin ${ }^{2,3}$ and Mohamed El-Sheemy ${ }^{1,2}$

\section{Retraction}

This article has been retracted [1] by the authors because errors were noted in the methodology employed in the experiments which invalidate the results reported. The authors apologise for any inconvenience caused.

\begin{abstract}
Author details
'University of Lincoln, Brayford Pool, Lincoln LN6 7TS, UK. ${ }^{2}$ Research \& Development, Lincoln County Hospital, Greetwell Road, Lincoln LN2 5QY, UK. ${ }^{3}$ Queens Medical Centre, University of Nottingham, Derby Road Nottingham, Nottingham NG7 2UH, UK.
\end{abstract}

Received: 26 September 2013 Accepted: 26 September 2013

Published: 22 October 2013

\section{Reference}

1. Jelly ND, Hussain II, Eremin J, Eremin O, El-Sheemy M: The stem cell factor antibody enhances the chemotherapeutic effect of adriamycin on chemoresistant breast cancer cells. Cancer Cell Int 2012, 12:21.

Submit your next manuscript to BioMed Central and take full advantage of:

- Convenient online submission

- Thorough peer review

- No space constraints or color figure charges

- Immediate publication on acceptance

- Inclusion in PubMed, CAS, Scopus and Google Scholar

- Research which is freely available for redistribution

Submit your manuscript at www.biomedcentral.com/submit
C Biomed Central 